\title{
Green finance incentives: An empirical study of the Pakistan banking sector
}

\section{Incentivos a las finanzas verdes: un estudio empírico del sector bancario de Pakistán}

Received: May 4, 2021

\begin{abstract}
In 21 century the climate change has become an important issues for businesses as well as stockholders. Consequently, to reduce carbon emission financial institutions offer green financing to businesses to mitigate this issue. However, the availability of green loan remains the important case. Therefore this research aims to know how this financing gap can be minimized. A panel design dataset was collected which consists of green financing data for the period 2009 to 2015 from 24 banks operating in Pakistan. We applied Two-stage Least Square Regression Analysis for data analysis. The results revealed that green loans are a less risky investments. Further, the findings also provides useful information to managers who look for grow their business loan and minimize default risk. This study contributes to the existing literature in green financing by filling the gap, particularly for developing countries through empirical evidence. The finding suggests that banks must invest more in green projects.
\end{abstract}

Keywords: green practices, sustainability, green banking, green environment, default risk.

\footnotetext{
${ }^{62}$ Ph.D. Scholar, Islamia College Peshawar, Pakistan.

63 Associate Professor, Islamia College Peshawar, Pakistan.

${ }^{64} \mathrm{Ph}$.D. Scholar, Islamia College Peshawar, Pakistan.

${ }^{65}$ Ph.D. Scholar, Islamia College Peshawar, Pakistan.
}

Accepted: June 12, 2021

\author{
Written by: \\ Fakhr E Alam Afridi ${ }^{62}$ \\ https://orcid.org/0000-0001-9776-5074 \\ Shahid Jan ${ }^{63}$ \\ https://orcid.org/0000-0001-8518-7668 \\ Bushra Ayaz ${ }^{64}$ \\ https://orcid.org/0000-0002-8999-4165 \\ Muhammad Irfan ${ }^{65}$ \\ https://orcid.org/0000-0002-9821-3383
}

\section{Resumen}

En el siglo XXI, el cambio climático se ha convertido en un tema importante para las empresas y los accionistas. En consecuencia, para reducir las emisiones de carbono, las instituciones financieras ofrecen financiamiento verde a las empresas para mitigar este problema. Sin embargo, la disponibilidad de préstamos verdes sigue siendo el caso importante. Por tanto, esta investigación tiene como objetivo saber cómo se puede minimizar este déficit de financiación. Se recopiló un conjunto de datos de diseño de panel que consiste en datos de financiamiento verde para el período 2009 a 2015 de 24 bancos que operan en Pakistán. Se aplicó el análisis de regresión de mínimos cuadrados en dos etapas para el análisis de datos. Los resultados revelaron que los préstamos verdes son una inversión menos riesgosa. Además, los hallazgos también brindan información útil a los gerentes que buscan hacer crecer sus préstamos comerciales y minimizar el riesgo de incumplimiento. Este estudio contribuye a la literatura existente sobre financiamiento verde al llenar el vacío, particularmente para los países en desarrollo a través de evidencia empírica. El hallazgo sugiere que los bancos deben invertir más en proyectos verdes.

Palabras clave: prácticas verdes, sostenibilidad, banca verde, medio ambiente verde, riesgo de incumplimiento. 


\section{Introduction}

In developing countries, high population growth is generating an extraordinary rise in demand for urban development, energy, and agricultural infrastructure (Falcone \& Sica, 2019). When fulfilling the growing demand the global environmental obligations will be a challenge. These issues promote major constraints in turning the economy into a green growth economy (Raberto, Ozel, Ponta, Teglio, \& Cincotti, 2019). Which shows the countless accountability of the stakeholders in the economy towards sustainability. Research shows construction activities are the major causes of resource depletion and environmental degradation all over the world (Aizawa \& Yang, 2010). Pakistan has already seen the impact of extreme weather events damaging infrastructure, affecting health, decreasing productivity, and reducing wealth (Mumtaz \& Smith, 2019). Such events can likely disrupt economic development, business activities, create resource shortages, damages the agricultural sector, and divert capital from technology and innovation to replacement and reconstruction in developing countries like Pakistan (Malik, Qasim, \& Saeed, 2018). While from an economic perspective such uncertainty about the future may lead to less investment (Migliorelli \& Dessertine, 2019). This arise the need to better understand that environment-related issues are sources of financial risk having many negative impacts on macroeconomic conditions and the financial stability of the country (Falcone, 2020). The country is in needs to factor in all aspects and takes steps to mitigate these challenges. Recently the term 'green finance' towards a low-carbon economy is getting attention from stakeholders which is by promoting sustainable environmental projects to mitigate climate change risk (Raberto et al., 2019).

Pakistan is blessed with enormous reserves of natural resources. The economy is growing 5.7\% consequently higher energy consumption demand for the growth (Mumtaz \& Smith, 2019) the country has a strong potential to produce energy through biomass and agriculture waste. Also, Pakistan can produce 2.3 million megawatts per annum in solar energy. Using their land and resources for cultivation Pakistan could also produce energy from biofuels. Pakistan can produce molasses up to two million tons a year which is enough amount for ethanol fuels for the country transport sector. Further, by Jatropha cruces plants cultivation a large amount of biodiesel for automobiles could be produced. Despite these resources, less production and exploration is mainly due to sufficient financing availability. Further, the energy crisis could be overcome by allocating biogas units at grid levels and in rural areas, and through biomass to energy production.

The banking sector is a key stakeholder in Pakistan's sustainable development goals achievement by providing green financing to industries at low-interest rates to mitigate environmental issues (Rehman, Ullah, et al., 2021). This way banks can attract environmentally conscious customers for hybrid car financing or green housing loans. However, the banking sector also shares the primary responsibility towards greening by preserving it through green practices and green financing policies (Raberto et al., 2019). Banks play important role in promoting ecological infrastructure financing such as; clean water, waste treatment plants, energy projects, and biofertilizer plants depend on the mode of investment (Islam \& Das, 2013). Further, by creating funds such as the "Climate Change Risk Fund" to assess environmental risks. This shows the greater importance of the bank primary social responsibility to motivate the concept of greening projects. Failure may lead to devastating impacts on the overall society (Dikau \& Volz, 2018). However, green services or products relating investments to be made according to the best interest of all parties. Moreover, there is no known study available particularly in the context of Pakistan. Therefore this study will provide a solid base for the upcoming research studies in the relevant area.

\section{Conceptual framework}

The country long-term social and economic development depends on its ability to safeguard its natural resources while growing (Rehman, Ishaque, et al., 2021). A coordinated approach across policy areas is needed to the cross-cutting nature of the green environment demand (Weber \& ElAlfy, 2019). The bank sector is important for environmental policies in two regards. The first aggregated environmental footprint is quite significant which shows a smaller environmental impact than large organizations (TaghizadehHesary \& Yoshino, 2019). The greater flexibility to the adoption of changing market conditions enables them to develop new practices or services including green ones (Moore \& Manring, 2009). Further, their flatter hierarchical structure and less formal style of communication offer a favorable new approach to green business 


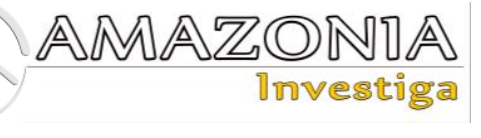

practices. This make banks the opportunity to initiate more eco-friendly products and services. This also helps in getting involved in new business opportunities and avail competitive advantage (Soundarrajan \& Vivek, 2016). This suggests that businesses face different hurdles towards environmentally friendly practices adoption as compared to big organizations. Such as in case of internal barriers which include insufficient financial and human resources, time constraints, and less awareness about environmental negative impacts or going green benefits. This highlights the importance of government support in their business models and environmentally friendly practices.

According to, (Meena, 2013) banks provide investments to lending business for mainly three major reasons: First for environmental risk management; second to avail business opportunities; and thirdly to gain reputation (Aizawa \& Yang, 2010). However, green credit or loan refers to the green products or services offered by banks to the private sector or the public. Just like green financing if it is considered as an environmental problem solution then the bridge which connects the financial institutions with the green industries is term as green credit (Zhou, Tang, \& Zhang, 2020). Figure 1 shows the $\mathrm{CO}_{2}$ emissions for the period 1960 to 2014 for Pakistan, Nepal, Afghanistan, India, and Sri Lanka which shows a direct relationship between the population and GHG emission. Pakistan ranked second while in the case of India per capita $\mathrm{CO}_{2}$ emissions increased to 1.76 from 1.0. In general lack of awareness and procedural difficulties are among major factor inflate the risks of the environmental problems associated in the South Asian region countries.



Afghanistan $\coprod_{\text {India }} \longrightarrow$ Sri Lanka ${ }_{\text {Nepal }} \longrightarrow$ Pakistan

Figure 1. $\mathrm{CO}_{2}$ Emissions in South Asia.

\section{Green finance}

There is a lack of consensus concerning a single definition of green finance. However, (Arkhipova, 2017) argued that green financing refers to investments in sustainable environmental projects, and solid policies that aim to encourage the development of the sustainable green economy. (Falconer \& Stadelmann, 2014) further added that green financing consists of; 1) financing of green policies for the public which motivate environmental projects and initiatives; 2) financing in environmentally friendly goods or services that minimize the damages to climate and environment; and 3) specifically deals with green investment. However, most of the available studies agree that green financing is related to sustainable green development projects which result in the betterment of the environment as well as society. This represents a broader term that includes all the financial investments aimed at environmental sustainability it includes borrowing also to encourage green projects. These financial projects can be related to industrial pollution control, greenhouse gas emissions, or biodiversity protection (Dikau \& Volz, 2021). Green financing in general a broader term which most studies available in the literature describe it as financing of sustainable environmentally friendly projects. However, to set boundaries in green financing and investments is the practical challenge relating. Green loan play role of a bridge which connects financial institutions and environment-friendly industries (Weber \& ElAlfy, 2019). 
Green bond issuance reached \$100bn in 2019 which is the fastest sum ever reached in one year. However, Asia-Pacific has been found lacking overall. Only 04 out of 35 banks across the region were able to meet half of the criteria for sustainability outlined (Falcone, 2020). However, to address environmental issues and promote green development with the support of the World Bank the government launched 40 billion PKR to Green Development Programe (Mumtaz \& Smith, 2019). This includes the Environment Endowment Fund (EEF) establishment which aims to promote environmental and sustainable living in the country through grant programs. According to WWF, Asia has in need of $\$ 5,000$ bn of sustainable development investment between now and the year 2030 (Volz, 2018). However, without the private sector help, government cannot all this finance, but it is the first step towards green financing in Pakistan.

The State Bank Of Pakistan (SBP), in 2017 launched green banking guidelines a set of green initiatives for banks. These guidelines directed the bank to take initiative by setting up green banking offices. The Pakistan government to reduce carbon emission and directed banks to offer environmental protection green loans, to help in reducing emission and less energy conservation projects to restrain the loans in high emission industries. Since then there is an increase in environment-friendly and sustainable projects (Malik et al., 2018). However, in comparison with developed countries, the financial system and capital markets in developing countries are still underdeveloped. SMEs generally in need and face financingrelated constraints in Pakistan, which is heavily related to the recent poor environmental performance (Volz, 2018).

In a World Bank survey for the period, 2006 to 2011 financial constraints and firm's environmental performance were examined, by controlling industrial sector, firm scale, and ownership. It was found that major financing obstacles in firms environmental performance (Georgeson, Maslin, \& Poessinouw, 2017). The constraint related to loan facilities is more severe because of the high probability of poor environmental performance. However, for sustainable development, the economic growth and environmental protection balance is a crucial element (Migliorelli \& Dessertine, 2019). This is because severe environmental pollution and fast economic development are both noticed in developing countries, particularly in Pakistan in recent decades. However, firms need funds to invest in green projects. How a firm's environmental performance in developing countries is affected by financing constraints is an emerging research phenomenon (Mumtaz \& Smith, 2019). However, firms are naturally more interested in profits seeking even if their products result in environmental deterioration (Moore \& Manring, 2009). In green finance, the Green Loan Policy is the driving force in Pakistan. The implementation of Pakistan Green Loan Policy can be used as an important reference for banks and other regulators. This study signifies three major parts; 1) because of the fewer green finance studies, 2) due to the significance of Pakistan loan policy. And 3) from bank perspective research. Further, this study will fill the existing gap in knowledge of the underlying research problem. Although there many empirical studies in the region available regarding sustainability performance, however, no known study is available in the context of Pakistan.

\section{Hypothesis development}

This study framework is based on (Raberto et al., 2019)study which describes banks' engagement in green financing projects mainly aimed; to explore new business opportunities; compliance risk; loan risk management; and building a positive corporate reputation. According to Koch et al. (2014), the degree of participation in green financing involves banks' perspectives such as; liquidity \& capital, securities and interest rate risks, and globalization and technology. This study investigates the decision maker's commitment to green finance to their expected outcomes.

One of the ways to improve financial performance is to issue more loans, however, with no excessive leverage. Banks have historically developed many products to generate more profits such as; personal mortgage loans, loan cards, car financing, etc. Previous research shows that green financing increases new opportunities for business (Arkhipova, 2017). However, it is difficult to assume that increase in green financing loans would have a large profitability impact as banks also generate and rely on other income sources (Rehman, Ullah, et al., 2021). Further low fraction of the total loans of a bank represents green loan only. Therefore it is essential to examine whether green financing growing rapidly and that expands faster than other product types.

As most previous studies suggest environmental issues consideration is primarily because of the 


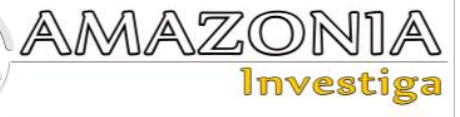

concern of risk management (Migliorelli \& Dessertine, 2019). Further, some researchers also find a correlation between loan risk and borrowers' sustainable performance (Falcone \& Sica, 2019). Therefore this study tests whether more green loans exists and whether this will increase more default risk for the bank when considering more high emission, overcapacity financing projects. To achieve study objectives lead to the development of the following hypotheses:

$\mathrm{H} 1$ : Green financing is expanding loan that grows at a faster rate than other traditional loans. $\mathrm{H} 2$ : Large shares of green financing in loan portfolio reduce total loan risk.

H3: Large shares of loans in loan portfolio to high-emission industries increases loan risk.

\section{Research method}

\section{Survey design and data collection}

This study used panel data set for quantitative analyses, which was built from scratch due to the lack of any available databases. Panel dataset consisted of repeated numbers of observations over a specified period. However, this also helps in analyzing how banks differ and develop green financing loan over the time. This study considered two criteria for the selected sample; 1) to be considered as "major banks"; 2) publically listed. There are 24 banks including commercial banks state-owned, policy banks, and city commercial banks in Pakistan (table 1). The term used in this study major banks can be found frequently in a various official press releases by SBP, and other financial news reports. Publicly listed banks must disclose financial statement requirements as set by the Pakistan securities regulatory commission therefore also included in the dataset. The sample consisted of 01 policy banks, 03 state-owned commercial banks, 08 joint-stock, and 12 commercial banks operating in the rural areas.

Table 1.

Banks in sample.

\begin{tabular}{llll}
\hline Type & Numbers & Publicly listed & Banks in Dataset \\
\hline Commercial banks & 31 & 19 & 12 \\
joint-stock banks & 10 & 08 & 08 \\
Government banks & 03 & 03 & 03 \\
Policy banks & 02 & 02 & 01 \\
\hline
\end{tabular}

\section{Financial indicators}

According to the basic listing requirements of the Pakistan Securities and Exchange Commission, the stock issuers are liable to publically disclose their financial information in the form of statements on regular basis. These financial reports can be seen on official banks' websites as well as other data provider's websites. Most of the sample financial data and indicators were available for the last 10 years. Data collected were only annually as green financing data were only available annually despite that mostly key financial data indicators were available quarterly (Mumtaz \& Smith, 2019). The dataset builds on all 09 indicators on "support and credit loan" as well as 03 other optional indicators; $\mathrm{CO} 2$ emission (in tons), "Average power (kw-h) consumed; and green loan training per employee in a year. Reduction in greenhouse gas emission from few banks reported as green loan, green loans in number, and loans to high energy consumption all categorized as green finance benefits.

\section{Results and discussion}

\section{Descriptive statistics}

Table 2 reported descriptive statistics of the banks in the sample in terms of green loan growth and total loan growth differences (standard deviation, mean, kurtosis, skewness, and count). The differences are calculated by the growth of total loans minus growth of green loan for the same year. The obtained statistics show green loan as expected grow at a faster rate than the total loan amount in the selected sample. However, the actual difference between growth rates varies due to the high standard deviation values. Further broken down of data based on types of banks, the data suggests that city commercial banks and state-owned banks had more growth in green loan loans than other commercial banks (joint-stock). On the other hand city commercial banks have very low green loan loans till 2012, then quickly caught up. As per the SBP record, the total value of green financing is 1.3 million USD. While 24 major banks contributed $10 \%$ of their total loan. The finding shows that green financing balances have 
been growing for the last 5 years. Overall the $25 \%$ growth rate has been maintained from 2006 to 2010 . The boost in the green loans has been noticed in the year 2013 to 2015 increase by $29 \%$. Which is the fastest growth during the observed time.

Table 2.

Descriptive statistics.

\begin{tabular}{llllll}
\hline Variable & Observations & Mean & SD & Min & Max \\
\hline Loan quality & 151 & 0.0239427 & 0.005936 & 0.011001 & 0.045258 \\
Inefficiency & 151 & 0.4292731 & 0.1110364 & 0.284463 & 0.938463 \\
NPL ratio & 151 & 0.0097327 & 0.0042845 & 0.001 & 0.0291 \\
ROA & 151 & 0.010321 & 0.0023224 & 0.0028 & 0.0156 \\
POGC & 151 & 0.0342357 & 0.0371159 & 0.0001 & 0.2215 \\
Solvency & 151 & 0.0583331 & 0.0114341 & 0.022241 & 0.067589 \\
Size & 151 & 0.0524165 & 0.0511425 & 0.0007144 & 0.1871266 \\
Type of bank & 151 & 2.635 & 1.266814 & 1 & 5 \\
\hline
\end{tabular}

The Hausman test results (table 3) favor the random-effects model over the fixed effects model $(\mathrm{P}=0.224)$. However, $\mathrm{LM}$ test values obtained suggest there is no enough evidence of difference across banks. Therefore OLS regression results are sufficient for the test. The result obtained from the OLS model suggests that the green loan increase growth rate will lead to an increased growth rate of the total loan portfolio. The overall result combing from descriptive statistics and OLS model demonstrated that green financing is expanding product or services that increase total loan growth rate for banks. For the $\mathrm{H} 2$ test regression analysis results from both the random-effect model (model 1), and the two-stage least square model (model 2) shows a significant effect on the POGC (table 3). Which suggests that banks have a lower NPL ratio with larger POGC. Therefore $\mathrm{H} 2$ of the study is supported. This implies that larger share allocation of green financing in loan portfolio reduces banks' NPL ratio (Raberto et al., 2019).

Table 3.

Model Hausman Test Results.

\begin{tabular}{|c|c|c|c|c|}
\hline Coefficients & (b) & (B) & $(\mathrm{b}-\mathrm{B})$ & Sqrt (diag(V_bV_B $))$ \\
\hline & 2 sls & RE & Difference & S.E. \\
\hline POGC & -.0752355 & -0.0328794 & -0.0541491 & 0.027024 \\
\hline Inefficiency & -0.0124764 & -0.0079633 & -0.0045132 & 0.0005863 \\
\hline ROA & -1.040637 & -0.0949626 & -0.0910114 & . \\
\hline Loan quality & 0.4158093 & 0.3258913 & 0.089918 & 0.0377025 \\
\hline Solvency & 0.0745217 & 0.0516749 & 0.0157359 & . \\
\hline Size & 0.0281542 & 0.0282386 & 0.0101651 & 0.0036678 \\
\hline \multicolumn{5}{|c|}{$\mathrm{b}=$ consistent under Ho and $\mathrm{Ha}$} \\
\hline \multicolumn{5}{|c|}{$\mathrm{B}=$ inconsistent under $\mathrm{Ha}$, efficient under $\mathrm{H}_{0}$; } \\
\hline \multicolumn{5}{|c|}{ Test: $\mathrm{H}_{0}$ : not systematic difference in coefficients } \\
\hline \multicolumn{5}{|c|}{$\operatorname{chi} 2(6)=(b-B)^{\prime}\left[\left(V \_b-V \_B\right)^{\wedge}(-1)\right](b-B)=3.82$} \\
\hline \multicolumn{5}{|c|}{ Prob $>$ chi $2=0.7008$} \\
\hline
\end{tabular}

Further, the Hausman test results provide endogeneity existence (table 3 ). The two-stage least square model (2sls) shows that a $1 \%$ increase in POGC will result in a $0.0007 \%$ reduction in the bank NPL ratio at a significance level of 5\%. To test Granger causality existence between NPL ration and POGC the NPL ration (dependent variable) in year $\mathrm{t}-1, \mathrm{t}-2$, and $\mathrm{t}-3$ was measured by POGC (table 4). The Model 3, 4, and 5 results indicated that there is no significance in the model result obtained. This implies that in the same year of issuance the green loan is unlikely to be the default. The 2sls model result efficiency confirms that green loan reduces the NPL ratio of the banks in the loan portfolio. Further, in model 2, the effects of ROA, size, loan equity, and bank types are aligned with the results expected (table 4). 
Table 4.

Test Results of Lagged Models (Test 2)

\begin{tabular}{|c|c|c|c|c|c|c|}
\hline & $\mathrm{t}-1$ (2sls) & & $\mathrm{t}-2$ (2sls) & & $t-3$ (2sls) & \\
\hline & POGC & NPLR & POGC & NPLR & POGC & NPLR \\
\hline POGCt-1 & & -0.040 & & & & \\
\hline POGCt-2 & & & & -0.031 & & \\
\hline POGCt-3 & & & & & & -0.034 \\
\hline $\begin{array}{l}\text { Bank type } \\
\text { (IV) }\end{array}$ & $0.013 * * *$ & & $0.012 * * *$ & & $0.011 * * *$ & \\
\hline $\mathrm{ROA}$ & -0.677 & $-0.937 * * *$ & -0.235 & $-0.832 * * *$ & -0.284 & $-1.025 * * *$ \\
\hline Loan quality & $1.730 * * *$ & $0.392 * * *$ & $1.270 * * *$ & $0.358 * * *$ & $1.224 * * *$ & $0.284 * * *$ \\
\hline Solvency & $0.370 *$ & $0.139 * * *$ & $0.469 * *$ & $0.158 * * *$ & $0.549 * *$ & $0.193 * * *$ \\
\hline Size & -0.040 & $0.022 *$ & -0.039 & 0.014 & -0.023 & 0.014 \\
\hline Inefficiency & $-0.052 *$ & $-0.013 * * *$ & -0.036 & $-0.008 * *$ & -0.019 & $-0.007 *$ \\
\hline Constant & -0.035 & $0.008 * *$ & -0.045 & 0.004 & $-0.056^{*}$ & 0.006 \\
\hline $\begin{array}{l}\text { Model } \\
\text { significance }\end{array}$ & $\mathrm{P}=0.0000$ & & $\mathrm{P}=0.0000$ & & $\mathrm{P}=0.0000$ & \\
\hline R-sq & 0.4191 & & 0.3807 & & 0.3703 & \\
\hline Obs & 144 & & 120 & & 96 & \\
\hline
\end{tabular}

For the test of $\mathrm{H} 3$, the same statistical tests were applied as test 2 on the two-high and one-over" (POTO) proportion. No significance effect was observed of POTO on the NPL ratio. The result imply that "two-high and one-over" in 2 to 3 years high polluting industries are likely to default. However, the result of all models does not show enough evidence that fewer allocating loans to two-high and one-over" will result in less NPL ration of the bank. The results show that; green financing is growing at a faster rate than total loans; allocating more shares in the loan portfolio of green loans can result in less loan risk of the bank. However, this study fails to record any evidence that fewer shares of loans in the loan portfolio of high pollution industries can decrease the NPL ratio.

\section{Conclusion}

In the past two decades to help tackle climate change the idea of putting a price on carbon dioxide emissions has been spreading around the globe (Migliorelli \& Dessertine, 2019). However, many countries found it difficult to level of carbon tax required to mitigate the impact of climate change (Falcone, 2020). For example, in Australia and France, efforts to increase carbon taxes were shelved after the resistance from the angry voters about energy prices increased (Falcone \& Sica, 2019). Similarly, Pakistan and other developing countries' capacity to reduce emissions is limited to funding and their unstable economic conditions (Malik et al., 2018). Green financing is a viable and ethically desirable area of growth for the stakeholders (Raberto et al., 2019). It acts as a bridge by linking specific climate-friendly to funds raised by banks (Migliorelli \& Dessertine, 2019). It has the revolutionize potential the way these financial institutions operate (Soundarrajan \& Vivek, 2016). Green project investments are essential for the maintenance and creation of sustainable infrastructures which are environmentally friendly (Volz, 2018). Banks' promotion and support of sustainable product financing represent their commitment to environmental issues (Rehman, Ullah, et al., 2021). Green finance products particularly largescale infrastructure products offering huge potential competitive benefits to banks. People becoming increasingly conscious of and concern with their behaviours towards environmental impacts. This also has an opportunity for banks to deliver sustainable, eco-friendly projects by playing a key role in society's development (Campiglio et al., 2018).

\section{Practical Implications and limitation}

The finding provides useful information to managers who look for grow their business loan and minimize default risk. Green financing offer opportunities for new businesses with lower risk. Further, green loans are expanding products which issuance increases business growth and reduces default risk in the loan portfolio. This study signifies three major parts; 1) because of the fewer green finance studies, 2) due to the significance of Pakistan loan policy. And 3) from bank perspective research. However, one of the major limitations of this study is the data availability. The green financing data accuracy is the biggest challenge. This makes the study result 
based on the limited variables. In other words, it is the closest presentation, not a truly accurate reality presentation. This research used the banking sector of Pakistan as a case study. Thus the results may not be directly applicable to other sectors or markets. In future studies, it would be interesting to compare results when more green finance data are available. Further other region's case studies may be helpful and the result may be applicable than to other markets.

\section{References}

Aizawa, M., \& Yang, C. (2010). Green credit, green stimulus, green revolution? China's mobilization of banks for environmental cleanup. The Journal of Environment \& Development, 19(2), 119-144.

Arkhipova, V. (2017). "Green Finance" as Recipe for Solving Global Problems. HSE economic journal, 21(2), 312-332.

Campiglio, E., Dafermos, Y., Monnin, P., RyanCollins, J., Schotten, G., \& Tanaka, M. (2018). Climate change challenges for central banks and financial regulators. Nature Climate Change, 8(6), 462-468.

Dikau, S., \& Volz, U. (2018). Central banking, climate change and green finance. Asian Development Bank Institute.

Dikau, S., \& Volz, U. (2021). Central bank mandates, sustainability objectives and the promotion of green finance. Ecological Economics, 184, 107022.

Falcone, P. M. (2020). Environmental regulation and green investments: The role of green finance. International Journal of Green Economics, 14(2), 159-173.

Falcone, P. M., \& Sica, E. (2019). Assessing the opportunities and challenges of green finance in Italy: An analysis of the biomass production sector. Sustainability, 11(2), 517.

Falconer, A., \& Stadelmann, M. (2014). What is climate finance? Definitions to improve tracking and scale up climate finance. Climate Policy Initiative.

Georgeson, L., Maslin, M., \& Poessinouw, M. (2017). The global green economy: a review of concepts, definitions, measurement methodologies and their interactions. Geo: Geography and Environment, 4(1), e00036.

Islam, M. S., \& Das, P. C. (2013). Green banking practices in Bangladesh. IOSR Journal of Business and Management, 8(3), 39-44.

Malik, S., Qasim, M., \& Saeed, H. (2018). Green finance in Pakistan: Barriers and solutions. Asian Development Bank Institute. Retrieved from https://www.adb.org/publications/greenfinance-pakistan-barriers-and-solutions Meena, R. (2013). Green banking: As initiative for sustainable development. Global Journal of Management and Business Studies, 3(10), 1181-1186.

Migliorelli, M., \& Dessertine, P. (2019). The rise of green finance in Europe. Opportunities and challenges for issuers, investors and marketplaces. Cham: Palgrave Macmillan.

Moore, S. B., \& Manring, S. L. (2009). Strategy development in small and medium sized enterprises for sustainability and increased value creation. Journal of Cleaner Production, 17(2), 276-282.

Mumtaz, M. Z., \& Smith, Z. A. (2019). Green finance for sustainable development in Pakistan. Islamabad Policy Res Inst J, 2, 1-34.

Raberto, M., Ozel, B., Ponta, L., Teglio, A., \& Cincotti, S. (2019). From financial instability to green finance: the role of banking and credit market regulation in the Eurace model. Journal of Evolutionary Economics, 29(1), 429-465.

Rehman, A., Ishaque, A., Malik, S., Rehman, S. U., Hussain, A., Khan, M., . . . Afridi, F. E. A. (2021). Exploring Asymmetric Nexus Between Tourism, Economic Growth and $\mathrm{CO} 2$ Emissions in the Context of Pakistan. International Journal of Energy Economics and Policy, 11(3), 338-345.

Rehman, A., Ullah, I., Ullah, Z., Zeeshan, M., Hussain, A., \& Rahman, H. U. (2021). Adoption of green banking practices and environmental performance in Pakistan: A demonstration of structural equation modelling. Environment, Development and Sustainability, 1-21.

Soundarrajan, P., \& Vivek, N. (2016). Green finance for sustainable green economic growth in India. Agricultural Economics, 62(1), 35-44.

Taghizadeh-Hesary, F., \& Yoshino, N. (2019). The way to induce private participation in green finance and investment. Finance Research Letters, 31, 98-103.

Volz, U. (2018). Fostering green finance for sustainable development in Asia.

Weber, O., \& ElAlfy, A. (2019). The development of green finance by sector The Rise of Green Finance in Europe (pp. 53-78). Springer.

Zhou, X., Tang, X., \& Zhang, R. (2020). Impact of green finance on economic development and environmental quality: a study based on provincial panel data from China. Environmental Science and Pollution Research, 27(16), 19915-19932. 